\title{
APLICAÇÃO DA REGRA DE CONFLITO DE INTERESSES STRICTO SENSU AO ACIONISTA CONTROLADOR DE SOCIEDADES DE ECONOMIA MISTA
}

Dissertação de Mestrado

Orientador: Professor Dr. José Tadeu De Chiara

UNIVERSIDADE DE SÃO PAULO

FACULDADE DE DIREITO

São Paulo - SP

2020 


\title{
FILIPE DA SILVA GOMES
}

\section{APLICAÇÃO DA REGRA DE CONFLITO DE INTERESSES STRICTO SENSU AO ACIONISTA CONTROLADOR DE SOCIEDADES DE ECONOMIA MISTA}

\begin{abstract}
Dissertação de Mestrado apresentada à banca examinadora do Programa de Pós-Graduação em Direito da Faculdade de Direito da Universidade de São Paulo, como exigência parcial para obtenção do título de Mestre em Direito, na área de concentração Direito Econômico e Economia Política do Departamento de Direito Econômico, Financeiro e Tributário (DEF), sob a orientação do Professor Dr. José Tadeu De Chiara.
\end{abstract}

\section{UNIVERSIDADE DE SÃO PAULO \\ FACULDADE DE DIREITO}

São Paulo - SP

2020 
Catalogaçăo da Publicaçăo

Serviço de Biblioteca e Documentação

Faculdade de Direito da Universidade de São Paulo

Gomes, Filipe da Silva

APLICAÇ̃̃ DA REGRA DE CONFLITO DE INTERESSES

STRICTO SENSU AO ACIONISTA CONTROLADOR DE SOCIEDADES

DE ECONOMIA MISTA ; Filipe da Silva Gomes ;

orientador José Tadeu De Chiara -- Săo Paulo, 2020.

228

Dissertaçăo (Mestrado - Programa de Pós-Graduaçăo em Direito Direito Econômico, Einanceiro e Tributário) -

Faculdade de Direito, Universidade de São Paulo, 2020 .

1. Conflito de interesses. 2. Sociedade de Economia Mista. 3. Ordem Econômica. 4. Situação juridica objetiva. 5. Poder de controle. I. De Chiara, José Tadeu, orient. II. Título. 
GOMES, Filipe da Silva. Aplicação da regra de conflito de interesses stricto sensu ao acionista controlador de sociedades de economia mista. 2020. 228 f. Dissertação (Mestrado em Direito) - Faculdade de Direito, Universidade de São Paulo, São Paulo.

Aprovado em:

BANCA EXAMINADORA:

Prof. Dr. José Tadeu De Chiara - Universidade de São Paulo 


\section{RESUMO}

GOMES, Filipe da Silva. Aplicação da regra de conflito de interesses stricto sensu ao acionista controlador de sociedades de economia mista. 2020. 228 f. Dissertação (Mestrado em Direito) - Faculdade de Direito, Universidade de São Paulo, São Paulo, 2020.

Este trabalho terá por propósito trazer critérios para a aplicação da regra de conflito de interesses de acionistas em assembleias gerais (artigo $115, \S 1^{\circ}$, da Lei 6.404/76) ao acionista controlador de sociedades de economia mista. Discutiremos nesse estudo a forma de compatibilização do complexo de poderes e deveres que circundam a atuação estatal com a regra societária de conflito de interesses.

Palavras chave: 1. Conflito de interesses 2. Sociedade de Economia Mista 3. Ordem Econômica 4. Situação jurídica objetiva 5. Poder de controle 


\begin{abstract}
GOMES, Filipe da Silva. Application of the stricto sensu conflict of interests rule to the controlling shareholder of mixed-capital companies. 2020. 228 pages. Master Degree Faculty of Law, University of São Paulo, São Paulo, 2020.

The purpose of this monograph is to set criteria for the application of the conflict of interests rule in shareholders' general meetings (article 115, §1, of Law No. 6.404/76) to the controlling shareholder of mixed-capital companies. We shall debate the compatibility of the set of powers and duties that are inherent to the state's action and the corporate rule of conflict of interests
\end{abstract}

Key-words: 1. Conflict of interests. 2. Mixed-capital companies. 3. Economic order. 4. Objective legal position. 5. Power of control. 


\section{SUMÁRIO}

RESUMO .............................................................................................................................

ABSTRACT ......................................................................................................................................9

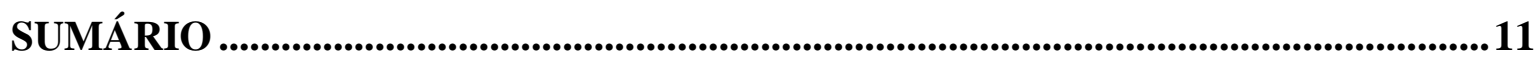

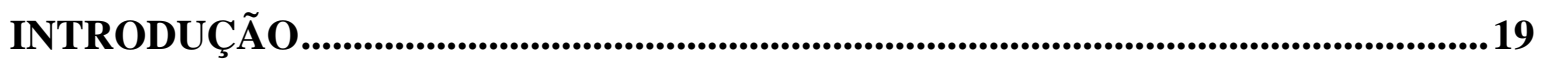

\section{CAPÍTULO I - OS FUNDAMENTOS PARA A ATUAÇÃO DO ESTADO COMO} ACIONISTA CONTROLADOR DE SOCIEDADE DE ECONOMIA MISTA ..........25

1.1. Pressupostos para a atuação do Estado enquanto acionista controlador

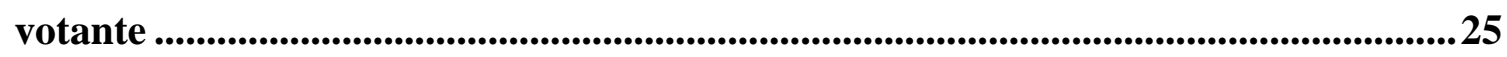

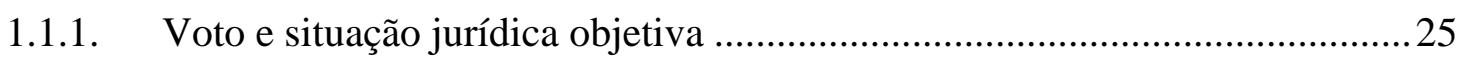

1.1.2. Ordem econômica e o conflito de interesses ............................................... 32

1.2. Aspectos formais da sociedade de economia mista .........................................38

1.2.1. O conceito jurídico de sociedade de economia mista e os requisitos para a sua

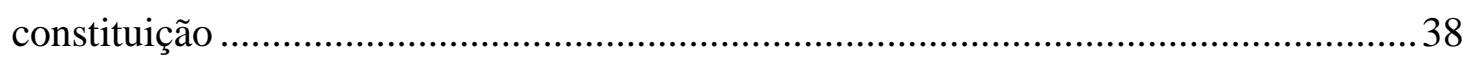

1.2.1.1. Personalidade jurídica de direito privado .......................................... 40

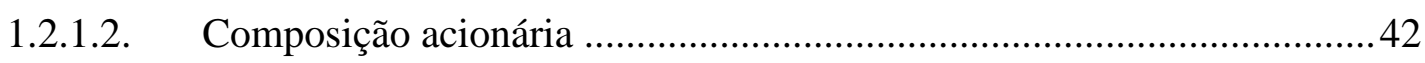

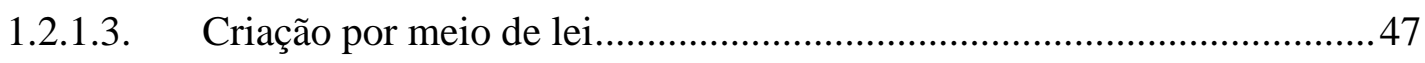

1.2.1.4. Realização de atividade econômica.................................................. 49

1.2.1.4.1. Iniciativa econômica (atividade econômica stricto sensu) ...................51

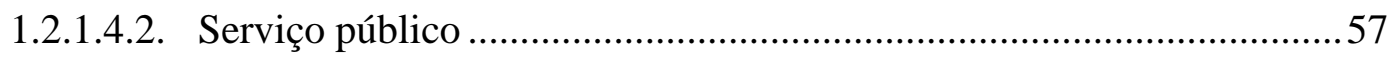

1.2.1.5. Forma de sociedade por ações ........................................................ 63

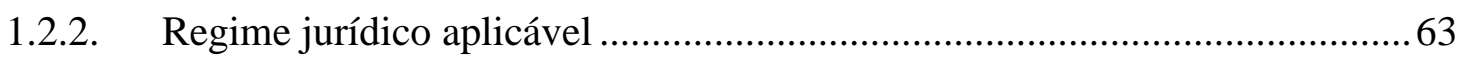

1.3. Vetores axiológicos da ordem econômica da Constituição de 1988 que orientam a atuação do Estado enquanto acionista controlador ...................................67

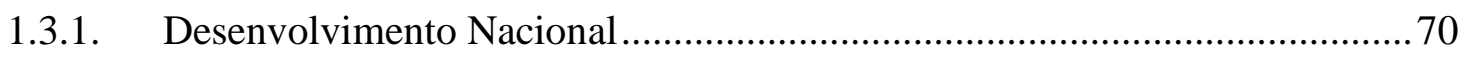

1.3.2. Função social da propriedade …......................................................... 75 
1.3.3. Soberania Econômica

\subsection{O artigo 238 da Lei 6.404/76 e a indisponibilidade dos interesses tutelados}

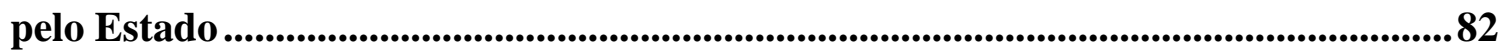

1.4.1. O "interesse público" que justifica a criação da sociedade de economia ......83

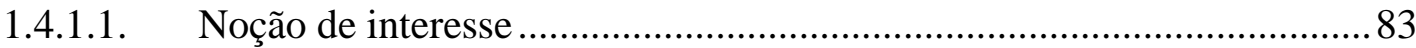

1.4.1.2. Categorias de interesse tutelados pelas sociedades de economia mista. 85

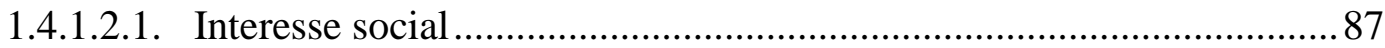

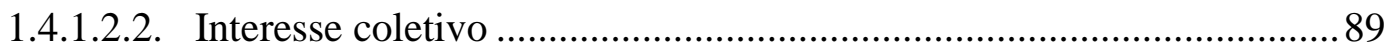

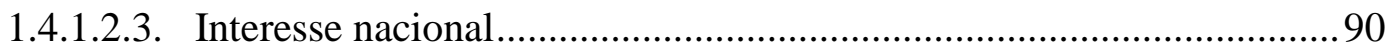

1.4.1.2.4. Interesse público e interesse geral ...............................................93

1.4.1.3. O “interesse público" a que se refere o artigo 238 da Lei 6.404/76 e a sua conciliação com o escopo lucrativo das sociedades por ações..................................98

1.4.2. Deveres do acionista controlador e indisponibilidade dos interesses que justificaram a criação da sociedade de economia mista ............................................. 113

1.5. Conclusões preliminares e considerações de síntese .....................................119 CAPÍTULO II - A DISCIPLINA SOCIETÁRIA DO CONFLITO DE INTERESSES

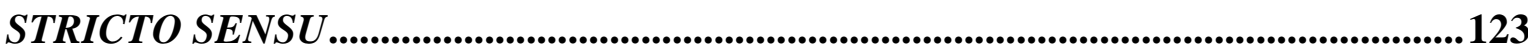

2.1. O objeto de tutela do conflito de interesses stricto sensu .............................123

2.1.1. Principais teorias sobre o interesse da companhia .................................... 124

2.1.2. O O interesse da companhia na Lei 6.404/76 e aplicação das teorias sobre o interesse social ao modelo jurídico da sociedade de economia mista

2.2. Interpretações sobre a regra de conflito de interesses stricto sensu no direito

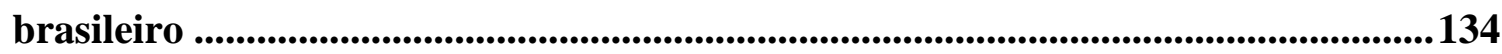

2.2.1. Correntes de interpretação da regra do conflito de interesses stricto sensu 134

2.2.1.1. Interpretação pelo critério material .................................................... 134

2.2.1.1.1. A técnica de criação de padrões de conduta ...................................... 136 
2.2.1.1.2. Evolução histórica da disciplina do conflito de interesses no direito societário brasileiro

2.2.1.1.3. O conflito de interesses nas relações entre companhias de mesmo grupo societário

2.2.1.1.4. Sanção do conflito de interesses stricto sensu pela anulabilidade da assembleia, presunção de boa-fé e princípio majoritário

2.2.1.2. Interpretação pelo critério formal

2.2.1.3. Uma terceira vertente?

2.2.2. Aplicação da regra de conflito de interesses stricto sensu nos tribunais e nos julgados administrativos da CVM

2.3. A experiência italiana na discussão sobre o conflito de interesses

2.3.1. Divergência doutrinária sobre a aplicação do conflito de interesses no direito italiano 160

2.3.2. A reforma societária de 2003 e a confirmação da vedação ex post facto .... 165

2.4. Conclusão preliminar e considerações de síntese 167

CAPÍTULO III - O ENCONTRO ENTRE AS DISCIPLINAS JURÍDICAS:

CONCLUSÕES SOBRE A PARTICIPAÇÃO DO ACIONISTA CONTROLADOR DE SOCIEDADE DE ECONOMIA MISTA EM ASSEMBLEIAS GERAIS DE ACIONISTAS.

3.1. Implicações das peculiaridades do regime do acionista controlador da sociedade de economia mista à interpretação da regra de conflito de interesses stricto sensu

3.2. Critérios para a identificação do conflito de interesses no voto do Estado enquanto acionista controlador de sociedades de economia mista e consequências jurídicas.

3.3. Crítica ao Caso Eletrobrás 182

CONSIDERAÇÕES FINAIS 


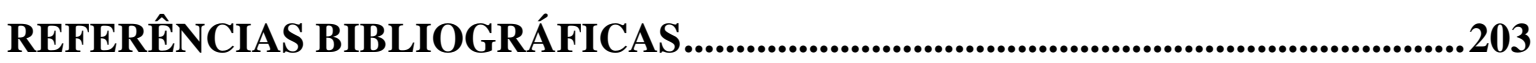

JURISPRUDÊNCIA E JULGADOS ADMINISTRATIVOS CITADOS......................227 


\section{INTRODUÇÃO}

Nas sociedades por ações, a assembleia geral de acionistas é o órgão de deliberação que tem poderes para definir os negócios relativos ao objeto da companhia e tomar as resoluções que julgar convenientes à sua defesa e desenvolvimento (artigo 121 da Lei $6.404 / 1976^{1}$ ). No contexto das sociedades de economia mista, a assembleia geral é, assim, responsável por decidir quando e como serão executadas diversas atividades de interesse da coletividade.

Acontece que a dinâmica dos conclaves assembleares de sociedades de economia mista ainda suscita muitas dúvidas, o que se deve à coexistência de deveres do seu acionista controlador, expressos nos preceitos constitucionais da ordem econômica e na lei que as cria, e os interesses utilitaristas de seus acionistas privados; há ainda grande incerteza sobre como esses dois polos de interesse interagem na estrutura interna da sociedade de economia mista.

Conforme bem aponta André de Laubadère, as organizações que possuem personalidade jurídica distinta daquela do Estado, mas que atuam como empresas estatais para a consecução de deveres daquele (caso da sociedade de economia mista), enfrentam um impasse na determinação do grau de sua relação de dependência com o Estado e, consequentemente, na definição de seu regime jurídico ${ }^{2}$.

Nesse contexto, o propósito do presente trabalho é analisar a aplicação da regra de conflito $^{3}$ de interesses em assembleias de acionistas prevista no $\operatorname{artigo} 115, \S 1^{\circ}$, da Lei ${ }^{\circ}$

\footnotetext{
1 "Art. 121. A assembleia-geral, convocada e instalada de acordo com a lei e o estatuto, tem poderes para decidir todos os negócios relativos ao objeto da companhia e tomar as resoluções que julgar convenientes à sua defesa e desenvolvimento"

${ }^{2}$ Cf. LAUBADÈRE, André de. Droit Public Économique. 2. ed. Paris: Dalloz, 1976, p. 503.

${ }^{3}$ Segundo Calixto Salomão Filho, a escolha do interesse protegido pode ser realizada por meio de duas soluções para regular a oposição de interesses, quais sejam (i) as Soluções Organizativas, por meio das quais a contraposição de interesses é disciplinada por meio de arranjos institucionais nos próprios órgãos societários da companhia, ou seja, os conflitos são resolvidos na estrutura dos próprios órgãos societários; ou (ii) as Regras de Conflito, por meio das quais a contraposição de interesses é disciplinada por meio de comandos normativos, isto é, as regras não solucionam o conflito de interesses por meio da estrutura societária, como ocorre nas soluções organizativas, mas tão somente pela disciplina normativa das relações intersubjetivas de conflito A presente dissertação terá como enfoque a disciplina do conflito de interesses tal como realizada no artigo 115 da Lei 6.404/76, isto é, a partir de uma regra de conflito. Cf. O Novo Direito Societário. 4. ed. São Paulo: Malheiros, 2011, pp. 104-112
} 
6.404/76 ao acionista controlador de sociedade de economia mista. A partir dessa temática, procuraremos traçar critérios para avaliar em que situações o voto proferido por esse acionista será legítimo, e em quais deve ser declarado nulo.

Em torno da estrutura do artigo 115 da Lei 6.404/76 orbita a tutela do interesse da companhia ${ }^{4}$ (artigo 115, caput, da Lei 6.404/76) e, para levar a cabo essa proteção, a Lei 6.404/76 elenca diversas hipóteses de vedação de voto aos acionistas da companhia em deliberações assembleares.

As hipóteses delineadas na primeira parte desse dispositivo legal, de modo geral, não suscitam grandes controvérsias hermenêuticas: (i) votações relativas ao laudo de avaliação de bens com que concorrer para a formação do capital social; e (ii) aprovação de suas contas, nas hipóteses em que exerça cargo de administração na companhia. Em tais hipóteses, o interesse individual do acionista é explicitamente colidente com o interesse da companhia.

Trata-se de situações em que o legislador considerou o potencial de lesão ao interesse social tão intenso e evidente que julgou melhor proibir o próprio exercício do direito de voto, a fim de evitar possíveis inconvenientes que a análise a posteriori do conteúdo do voto poderia gerar. As referidas hipóteses, portanto, são exemplos de situações específicas em que o legislador estabeleceu um regime de presunção absoluta de que o exercício do direito de voto contrariaria o interesse da companhia e, por isso, veda-o. ${ }^{5}$.

Por sua vez, a terceira hipótese do dispositivo em comento (deliberações que possam beneficiar o acionista de modo particular) suscita algum debate na doutrina, prevalecendo, em geral, o entendimento de que o benefício particular de que trata o parágrafo $1^{\circ}$ do artigo 115 da Lei 6.404/76 é um favor lícito concedido a um acionista ou a uma classe de acionistas, em razão de sua condição de acionista e que viola a isonomia, motivo pelo qual o acionista ou classe de acionistas beneficiados não poderiam participar da deliberação

\footnotetext{
${ }^{4}$ Cf. MARTINS, Fran. Comentários à Lei das Sociedades Anônimas. v. II, t. I, Rio de Janeiro: Forense, 1978, pp. 77-78.

${ }^{5}$ Cf. GUERREIRO, José Alexandre Tavares; TEIXEIRA, Egberto Lacerda. Das Sociedades Anônimas no Direito Brasileiro. v. II. São Paulo: Bushatsky, 1979, pp. 277-278.
} 
sobre o tema, sob o princípio de que ninguém pode ser juiz de causa própria (nemo iudex in causa propria) ${ }^{6}$.

O nosso estudo diz respeito à quarta hipótese de vedação de voto prevista no parágrafo $1^{\circ}$ do artigo 115 da Lei 6.404/1976: o "interesse conflitante com o da companhia", expressão que, diante das demais hipóteses de conflito supra mencionadas, será particularizada neste trabalho a partir da denominação de "conflito de interesse stricto sensu"7.

A ambiguidade da expressão do artigo $115, \S^{\circ}$, da Lei $6.404 / 76$, objeto desta dissertação, é, por si só, um dos temas mais controvertidos do direito societário brasileiro ${ }^{8}$. Mas o nosso estudo irá além: analisará a aplicação dessa regra ao acionista controlador de sociedades de economia mista, particularidade que torna a discussão sobre o conflito de interesses stricto sensu ainda mais complexa, posto que o artigo 238 da Lei 6.404/1976 estabelece que a "pessoa jurídica que controla a companhia de economia mista tem os

\footnotetext{
${ }^{6}$ Esse é o entendimento de Erasmo Valladão Azevedo Novaes e França, vide FRANÇA. Erasmo Valladão Azevedo e Novaes. Ainda o conceito de benefício particular: anotações ao julgamento do processo CVM N. RJ-2009/5.811. In: Conflito de interesses nas assembleias nas assembleias de S.A., (e outros escritos sobre conflito de interesses). 2. ed. São Paulo: Malheiros, 2014, pp. 294-295. Os exemplos de benefícios particulares comumente citados pela doutrina são os aludidos por Miranda Valverde, ainda sob a égide do Decreto 2.627/40. $\mathrm{O}$ autor do anteprojeto que resultou no Decreto-Lei 2.627/40 indica como hipótese de benefício particular a bonificação atribuída a quaisquer acionistas, vide VALVERDE, Trajano de Miranda. Sociedades por Ações (comentários ao decreto-lei $\mathbf{n}^{\mathbf{0}} \mathbf{2 . 6 2 7}$, de 26 de setembro de 1940). 3. ed. Rio de Janeiro: Forense, 1959, p. 67. Outro exemplo comumente citado é o das partes beneficiárias, as quais, após a reforma introduzida pela Lei 10.303/2001, passaram a ser vedadas por companhias abertas, nos termos da atual redação do parágrafo único do artigo 47 da Lei 6.404/76.

Assim, Erasmo Valladão Azevedo e Novaes França argumenta que o benefício particular caracterizar-se-ia pela licitude da vantagem potencialmente obtida, não sendo aproveitada pelos demais acionistas, violando, assim, a regra geral da igualdade que vige nas relações societárias. Daí decorreria o impedimento de voto do acionista, observado que não é lícito a ninguém ser juiz de causa própria (nemo iudex in causa propria).

A seu turno, em posição minoritária na doutrina, Modesto Carvalhosa entende que o benefício particular resulta da comparação dos efeitos de determinada operação entre os acionistas envolvidos. Assim sendo, sempre que algum acionista (ou classe de acionistas) for favorecido em detrimento dos demais, tem-se o benefício particular. O benefício particular é analisado, portanto, somente pela perspectiva da quebra da igualdade entre os acionistas, sendo os acionistas não beneficiados considerados prejudicados com o resultado da deliberação (vide CARVALHOSA, Modesto. Comentário à Lei de Sociedades Anônimas. v.2. 5. ed. São Paulo: Saraiva, 2011, pp. 516-518). Em outras palavras, a extensão do conceito de benefício particular de que trata o parágrafo $1^{\circ}$ do artigo 115 da Lei das S.A. seria ampla. Nesse sentido, Modesto Carvalhosa inclusive equipara o benefício particular às vantagens indevidas mencionadas no caput daquele dispositivo legal, a partir da consideração de que ambos supostamente causariam efeitos adversos aos acionistas. Isto é, tanto as "vantagens a que não faz jus”, estabelecidas no caput do artigo 115 da Lei das S.A., quanto qualquer benefício que o acionista aufira na deliberação assemblear seriam vedados, tendo em vista o princípio da igualdade entre todos os acionistas, ressalvados as diversas prerrogativas de cada classe de ações (vide Ibid., p. 540)

${ }^{7}$ Nesse sentido: ARAG ̃̃O, Paulo Cezar. Apontamentos sobre Desvios no Exercício do Direito de Voto: Abuso de Direito, Benefício Particular e Conflito de Interesses. In: WARDE JUNIOR, Walfrido Jorge et al (coords.). Direito Empresarial e Outros Estudos de Direito em homenagem ao Professor José Alexandre Tavares Guerreiro. São Paulo: Quartier Latin, 2013, p. 189

${ }^{8}$ Vide a respeito as controvérsias doutrinárias e jurisprudenciais mencionadas no capítulo II desta dissertação.
} 
deveres e responsabilidades do acionista controlador (artigos 116 e 117), mas poderá orientar as atividades da companhia de modo a atender ao interesse público que justificou a sua criação".

Nota-se que esse dispositivo indica, de forma enigmática, a existência de um modo de conciliação entre a consecução da parcela de deveres do Estado que justifica a criação da sociedade de economia mista e os fins próprios de uma empresa regida por regime de direito privado, ao qual a sociedade de economia mista se submete por expressa disposição legal e constitucional ${ }^{9}$. Diante desse cenário, o objetivo desta dissertação será investigar em que extensão a atuação do acionista controlador nas deliberações assembleares da sociedade de economia mista configura um conflito de interesses stricto sensu vedado pelo parágrafo $1^{\circ}$ do artigo 115 da Lei 6.404/76.

Para realizar esse propósito, o presente estudo será dividido em três capítulos.

O primeiro capítulo versará sobre os fundamentos para a atuação do Estado enquanto acionista controlador da sociedade de economia mista. Esse capítulo terá por objetivo trazer à baila alguns conceitos essenciais para se compreender as particularidades e os critérios para a atuação do Estado enquanto acionista controlador da sociedade de economia mista.

Esse estudo se faz necessário visto que o acionista controlador da sociedade de economia mista se submete a um complexo de poderes e deveres ao qual acionistas controladores das demais sociedades por ações não se submetem. Não é por outro motivo que o artigo 238 da Lei 6404/76 impõe ao acionista controlador da sociedade de economia mista o dever de orientar "as atividades da companhia de modo a atender ao interesse público que justificou a sua criação".

Assim, o primeiro capítulo se justifica na medida em que as peculiaridades do acionista controlador da sociedade de economia mista fazem com que a regra do conflito de interesses stricto sensu deva ser interpretada de forma particular a este acionista. Afinal, conforme a lição de André de Laubadère, o princípio da igualdade - um dos princípios fundamentais do direito público econômico - impede a tomada de decisões discriminatórias a indivíduos em situações comparáveis (situations comparables) ou o oferecimento de

${ }^{9}$ Vide artigo $173, \S 1^{\circ}$, II, da Constituição de 1988 , artigo $4^{\circ}$ da Lei $13.303 / 2016$, e artigo $5^{\circ}$, III, do DecretoLei 200/1969 
tratamentos equitativos para sujeitos que se encontrem em situações não equivalentes (situations non comparables ${ }^{10}$.

Em outras palavras, considerando-se as especificidades do regime a que se sujeita o acionista controlador da sociedade de economia, a aplicação da regra de conflito de interesses stricto sensu não pode ser analisada sob o mesmo viés de um acionista comum. Isso implicaria adotar uma solução equiparada para situações jurídicas não comparáveis e, portanto, representaria uma violação ao princípio da igualdade ${ }^{11}$.

Ato contínuo, o segundo capítulo desta dissertação terá por finalidade investigar a disciplina societária do conflito de interesses stricto sensu, tal como positivado no artigo $115, \S 1^{\circ}$, da Lei 6.404/76, demonstrando as intricadas discussões sobre o modo de aplicação da regra do conflito de interesses stricto sensu no direito societário brasileiro. Esse tópico se desviará momentaneamente da problemática do acionista controlador da sociedade de economia mista, e procurará trazer conclusões sobre a forma de aplicação da regra de conflito de interesses stricto sensu no direito brasileiro, um dos maiores objetos de debate no campo societário atualmente.

Por fim, o terceiro capítulo confrontará e conciliará os temas estudados nos dois primeiros capítulos e procurará estabelecer critérios para a aplicação da regra de conflito de interesses stricto sensu ao acionista controlador de sociedades de economia mista.

${ }^{10}$ Cf. LAUBADÈRE, op. cit. (nota $\mathrm{n}^{\mathrm{o}} 2$ 2, supra), p. 282.

${ }^{11}$ Cf. Ibid., pp.282-283. 


\section{CONSIDERAÇÕES FINAIS}

É corrente no jargão societário a utilização da expressão direito de voto, que remete a um direito subjetivo do acionista. Entretanto, cremos ter demonstrado no curso deste trabalho a insuficiência de tal noção para explicar a complexidade que representa o voto de acionistas em assembleias, em especial no que se refere ao acionista controlador da sociedade de economia mista.

O nosso esforço de pesquisa partiu da seguinte questão: em que hipóteses o voto do acionista controlador da sociedade de economia mista caracteriza um conflito de interesses stricto sensu, vedado pela norma do artigo 115 , $\S 1^{\circ}$, da Lei 6.404/76.

A partir da noção de situação jurídica objetiva e a sua contraposição com a noção de direito subjetivo, pudemos concluir que o acionista controlador da sociedade de economia mista se encontra em uma situação jurídica objetiva, circundado por deveres, para o cumprimento dos quais a ordem jurídica lhe atribui poderes. $\mathrm{E}$ a forma de consecução desses deveres será delimitada nos preceitos da ordem econômica, entendida como a parcela da ordem jurídica que disciplina e institucionaliza um modo de produção econômico.

Para que pudéssemos responder à pergunta que originou o presente trabalho, foi necessário investigar cada um dos elementos que compõem o preceito do artigo 238 da Lei 6.404/76, quais sejam: (i) o "interesse público" que justifica a criação da companhia de economia mista; e (ii) os deveres e responsabilidades do seu acionista controlador.

Como visto, a expressão "interesse público" constante do artigo 238 da Lei 6.404/76 não significa um tipo de interesse único, mas sim as categorias de interesse tuteladas pelo Estado quando da atuação no domínio econômico, tais como o interesse social, o interesse coletivo, o interesse nacional e o interesse geral. Não incluímos nesse campo (ao menos diretamente) o interesse patrimonial do Estado - denominado pela doutrina de interesse público secundário e por nós denominado de interesse público - pois tal interesse não é um fim em si mesmo na exploração da atividade econômica lato sensu, mas tão somente um objetivo mediato para a consecução de deveres do Estado.

Ao que tudo indica, a utilização da expressão "interesse público" no artigo 238 da Lei 6.404/76 está inserida no contexto de uma comum generalização do conteúdo do 
interesse público, significando tudo o que tenha a mínima pertinência com as funções do Estado. No entanto, como visto, o tratamento das categorias de interesses tuteladas pelo Estado como um genérico "interesse público" somente faz sentido a partir de um postulado de Estado liberal em que a única distinção que se faz necessária é a do interesse público com a do interesse privado, o que não é o caso da ordem econômica da Constituição Federal de 1988.

Pudemos também concluir que a individualização das categorias de interesses atendidas pelo Estado é relevante para os propósitos do nosso trabalho na medida em que a Lei 6.404/76 não autoriza o acionista controlador da sociedade de economia mista a atuar em nome de um "interesse público" etéreo e genérico. O interesse tutelado pela sociedade de economia mista é aquele dedutível da lei que autoriza o funcionamento da companhia mista, e poderá ser configurado a partir das categorias de interesse supramencionadas.

Nesse contexto, concluímos que devem ser afastadas interpretações fundamentalistas que sustentam que o lucro é elemento primordial da sociedade de economia mista e que não pode ser, de forma alguma, preterido no exercício da atividade econômica. $\mathrm{Na}$ verdade, como pudemos analisar no curso deste trabalho, a exploração da atividade econômica lato sensu possui caráter manifestamente instrumental, de modo a permitir ao ente estatal controlador da sociedade de economia mista a consecução da missão pública que justificou a sua criação. Em outras palavras, o lucro, para a sociedade de economia mista é um efeito decorrente da sua constituição enquanto exploradora de atividade econômica lato sensu, como objetivo mediato para a consecução das finalidades a que está vinculada.

Dentro da substância da atividade realizada por cada sociedade de economia mista, o correto equacionamento entre a noção de lucro e o interesse objeto de tutela pela sociedade de economia mista se resolverá a partir de uma lógica de economicidade, a qual determina que o acionista controlador da sociedade de economia mista deve perseguir a maior eficácia social com os recursos disponíveis para a atividade empresarial.

Após essas considerações, analisamos o segundo elemento do artigo 238 da Lei 6.404/76, quais sejam os deveres e responsabilidades do acionista controlador da sociedade de economia mista. Nessa seara, concluímos que o exercício do poder de controle na sociedade de economia mista somente será legítimo se estiver em linha com as finalidades que o vinculam, motivo pelo qual a expressão "poderá" constante do dispositivo legal em 
comento, na verdade, significa não uma faculdade, mas um verdadeiro dever ao acionista controlador da companhia mista. Deste modo, concluímos que o que a ordem jurídica sanciona nos atos do acionista controlador da companhia mista é o desvio de finalidade.

Nesse contexto, a análise do voto do acionista controlador da sociedade de economia mista não poderá ser centrada no que melhor que se poderia ter realizado naquelas circunstâncias (conveniência e oportunidade), ou seja, não se analisa o seu mérito, mas tão somente a sua legitimidade, isto é, a sua harmonia com os fins previsto em lei.

No segundo capítulo deste trabalho, investigamos a disciplina societário do conflito de interesses stricto sensu, objeto de um dos maiores debates no direito societário brasileiro. A partir do confronto das diversas posições doutrinárias, jurisprudenciais e, inclusive, com o auxílio das discussões presentes no direito italiano, concluímos que o conflito de interesses stricto sensu vedado pela previsão do artigo $115, \S 1^{\circ}$, da Lei 6.404/76 ocorre quando o interesse da companhia é sacrificado em favor de um interesse extrassocial, por meio do exercício do direito voto (critério material de interpretação do conflito de interesses stricto sensu).

Por esse motivo, o acionista não pode ser impedido de votar na assembleia, mesmo que possua um interesse potencialmente conflitante. O conteúdo do seu voto somente é passível de questionamento após a ocorrência da assembleia, para que se possa analisar, de forma concreta, se o voto atendeu aos parâmetros legais.

No terceiro capítulo, unimos as investigações realizadas nos dois capítulos precedentes para chegarmos às conclusões de como se concretiza o conflito de interesses stricto sensu especificamente na atuação do acionista controlador da sociedade de economia mista.

Nesse sentido, pudemos concluir que, para além dos argumentos frequentemente evocados pela doutrina para a fundamentação da interpretação da regra do artigo $115, \S 1^{\circ}$, da Lei 6.404/76 pelo critério material, as particularidades da sociedade de economia mista e do seu acionista controlador reforçam essa posição.

Na medida em que a legislação ordinária impõe ao Poder Público o poder de controle da sociedade de economia mista com a finalidade de possibilitar ao Estado atuar no interior da sociedade na condição de Estado-Poder, não é lícito ao presidente da assembleia 
geral impedir, de antemão, que o Poder Público vote e cumpra a missão determinada por lei, sem sequer avaliar o conteúdo do voto e o seu impacto na esfera de terceiros. Somente a tutela jurisdicional poderia desconstituir tal ato, ou seja, somente mediante a provocação ao competente órgão jurisdicional o ato do acionista controlador da sociedade de economia mista poderia ser desfeito, em razão de desvio de finalidade. Esse acionista não pode ser impedido de votar, pois sempre age para o cumprimento de uma lei específica que autorizou a criação da sociedade de economia mista.

No mais, em linha com as discussões da doutrina italiana, a interpretação da regra de conflito de interesses pelo critério formal (impedimento de voto a priori) resulta na subversão do princípio majoritário, princípio estruturante do direito societário. Ocorre que a sociedade de economia mista é modelo jurídico que possui como pressuposto determinado por lei o poder de controle exercido pelo Poder Público para direcionamento do empreendimento que justifica a sua criação, ao que se contrapõem deveres e responsabilidades. Deste modo, na medida em que os acionistas minoritários não possuem o dever de realizar a missão pública a que se destina a companhia mista, e nem mesmo as sanções para o caso de descumprimento dela, não é possível impedir a priori o voto do acionista controlador da sociedade de economia mista, sob pena de subversão da finalidade da companhia mista.

Diante desse cenário, traçamos dois critérios para a identificação do conflito de interesses stricto sensu na atuação do acionista controlador de sociedades de economia mista.

Em primeiro lugar, deve-se analisar a ocorrência de um dano ou potencial dano à companhia, um sacrifício ao interesse da companhia mista a partir a realização do voto na assembleia. O passo seguinte é proceder à investigação da finalidade do voto proferido pelo acionista controlador da sociedade de economia mista no conclave assemblear. A finalidade é o elemento chave para se avaliar a licitude ou ilicitude do voto pois, nos termos dos artigos 238 da Lei $6.404 / 76$ e $4^{\circ}, \S 1^{\circ}$, da Lei 13.303/2016, o acionista controlador da sociedade de economia mista possui o dever direcionar a execução da atividade empresarial em linha com os objetivos que justificaram a criação da sociedade de economia mista, cristalizados na lei autorizadora.

Caso o acionista controlador da sociedade de economia mista se desvie dos propósitos da lei que justificou a criação da companhia de economia mista, incorrerá em 
desvio de poder (desvio de finalidade), aspecto que macula a legalidade do voto e caracterizará o conflito de interesses stricto sensu vedado pelo artigo $115, \S 1^{\circ}$, da Lei $6.404 / 76$.

Por fim, como cremos ter demonstrado no curso deste trabalho, as ideias aqui propostas devem ser encaradas com dinamismo, na medida em que os preceitos da ordem econômica que balizam a atuação do acionista controlador da sociedade de economia mista são mutáveis conforme o contexto histórico e político. Esperamos, então, que o presente trabalho sirva de estímulo para o contínuo desenvolvimento do tema. 


\section{REFERÊNCIAS BIBLIOGRÁFICAS}

AGUILLAR, Fernando Herren; PINTO, Henrique Motta; PINTO JÚNIOR, Mário Engler. Empresas Estatais. São Paulo: Saraiva, 2013.

ALCHIAN, Armen; DEMSETZ, Harold. Production, information costs and economic organization. In: American Economic Review, n. 62, 1972

ALCONTRES, Alberto Stagno; NICCOLINI, Giuseppe (coords). Società di capitali. Napoli: Jovene Editore, 2004

ALEXANDER-SMITH, Robin. Conflicts of Interest: Multiple Representations. Chicago: American Bar Association - Center for Professional, 1983.

AMARAL, Antônio Carlos Cintra de. Conceito de Sociedade de Economia Mista no Contexto da Nova Lei das Sociedades Anônimas. In: Revista de Direito Públic, n. 37, pp. 25-34, 1976.

ANGELO, Riccio, Il presidente dell'assemblea può, dunque, escludere dal quorum deliberativo il voto espresso dal socio in conflitto di interessi. In: Contratto e impresa, $\mathrm{n}$. 3, pp. 1.079-1.082, 2001.

ARAGÃO, Paulo Cezar. Apontamentos sobre Desvios no Exercício do Direito de Voto: Abuso de Direito, Benefício Particular e Conflito de Interesses. In: WARDE JUNIOR, Walfrido Jorge et al (coords.). Direito Empresarial e Outros Estudos de Direito em homenagem ao Professor José Alexandre Tavares Guerreiro. São Paulo: Quartier Latin, 2013, pp. 184-214

ASCARELLI, Tullio. Studi di Diritto Comparato e in Tema di Interpretazione. Milão: Giuffrè, 1952. 
Obligazzioni Pecuniarie. Bolonha: Nicola Zanichelli Editore, 1971.

Problemas das Sociedades Anônimas e Direito Comparado.

Campinas: Bookseller, 1999.

ASQUINI, Alberto. Conflitto d'interessi tra il sócio e la società nelle deliberazioni di assemblee delle società per azioni, in Rivista del Diritto Commerciale e del Diritto Generale delle Obbligazioni, v. XVII, pp. 652-677, 1919.

ATALIBA, Geraldo. Empréstimos Públicos e Seu Regime Jurídico. São Paulo: Revista dos Tribunais, 1973.

Empresa estatal delegada de serviço público tem superávit ou déficit (não é devedora da contribuição social sobre o lucro). Revista de Direito Administrativo. n. 200. São Paulo, pp. 348-362, 1995

ATANASOV, Vladimir; BLACK, Bernard; CICCOTELLO, Conrad,. Self-Dealing by Corporate Insiders: Legal Constraints and Loopholes disponível em http://papers.ssrn.com/sol3/papers.cfm?abstract_id=1714591 [08.10.2015].

Law and

Tunneling, disponível em http://papers.ssrn.com/sol3/papers.cfm?abstract_id=1444414 [08.10.2015]

AXELROD, Robert. Conflict of interest: a theory of divergent goals with applications to politics. Chicago: Markham Publishing Co., 1970.

BALDWIN, Fred. Conflicts of Interest: Corporate-Governance controversies. Lexington: Lexington Book, 1984.

BARROSO, Luis Roberto. A Ordem Econômica Constitucional e os Limites à Atuação no Controle de Preços. In: BARROSO, Luís Roberto; CLÈVE, Clemerson Merlin (orgs.). Doutrinas Essenciais: Direito Constitucional. v. 6. São Paulo: Revista dos Tribunais, 2011, pp. 649-678 
. Modalidades de Intervenção do Estado na Ordem Econômica.

Regime Jurídico das Sociedades de Economia Mista. Inocorrência de Abuso de Poder Econômico. In: BARROSO, Luis Roberto. Temas de Direito Constitucional. 2. ed. Rio de Janeiro: Renovar, 2003.

Regime Jurídico das Empresas Estatais. In: Revista de Direito

Administrativo, n. 242, 2005.

BERCOVICI, Gilberto. A Constituição de 1988 e a Função Social da Propriedade. In: BARROSO, Luís Roberto; CLÈVE, Clemerson Merlin (orgs.). Doutrinas Essenciais: Direito Constitucional. v. 6. São Paulo: Revista dos Tribunais, 2011.

Constituição Econômica e Desenvolvimento: uma Leitura a partir da Constituição de 1988. São Paulo: Malheiros, 2005.

; MASSONETTO, Luís Fernando. A Constituição Dirigente Invertida: a Blindagem da Constituição Financeira e a Agonia da Constituição Econômica. Boletim de Ciências Econômicas, Coimbra, Portugal, v. XLIX, pp. 66-71, 2006

Constituição e Superação das Desigualdades Regionais. In: GRAU, Eros Roberto; GUERRA FILHO, Willis Santiago. Direito Constitucional: Estudos em Homenagem a Paulo Bonavides. São Paulo: Malheiros, 2001.

; OCTAVIANI, Alessandro. Direito e Subdesenvolvimento. In: OCTAVIANI, Alessandro. Estudos, Pareceres e Votos de Direito Econômico. São Paulo: Editora Singular, 2014

Desenvolvimento, Estado e Administração pública. In: CARDOZO,

José Eduardo Martins et al. Direito Administrativo Econômico. São Paulo: Atlas, 2011.

Desigualdades Regionais, Estado e Constituição. São Paulo: Max

Limonad, 2003. 
Direito Econômico do Petróleo e dos Recursos Minerais. São

Paulo: Quartier Latin, 2011

Entre o Estado Total e o Estado Social: Atualidade do Debate

sobre Direito, Estado e Economia na República de Weimer. Tese (Livre Docência), Faculdade de Direito, Universidade de São Paulo, São Paulo, 2003.

. O Ainda Indispensável Direito Econômico. In: BENEVIDES, Maria Victoria de Mesquita; BERCOVICI, Gilberto; MELO, Claudineu de (orgs.). Direitos Humanos, Democracia e República: Homenagem a Fábio Konder Comparato. São Paulo: Quartier Latin, 2009.

A Constituição Brasileira de 1988, as Constituições Transformadoras e o Novo Constitucionalismo Latino-Americano. In: Revista Brasileira de Estudos Constitucionais, n. 26, 2013.

. Mixed-Capital Companies and the Brazilian Constitution of 1988.

Revista Eletrônica da Academia Brasileira de Direito Constitucional, n. 7, pp. 72-93, 2015.

Natureza jurídica de sociedade anônima privada com participação acionária estatal. Revista de Direito Mercanti, Industrial, Econômico e Financeiro. n. 153/154. São Paulo, pp. 297/317, 2010

BERLE, Adolf.; MEANS, Gardiner. The Modern Corporation and Private Property. Nova York: The Macmillan, 1940

BERTOLOTTI, Angelo; SPIOTTA, Marina. Assemblea e Amministratori. Turim: UTET Giuridica, 2013

BETTI, Emilio. Interpretazione della legge e degli atti giuridici - teoria generale e dogmática. Milão: Giuffrè, 1971. 
Teoria Generale del Negozio Giuridico. Napoli: Edizioni Scientifiche Italiane, 2002.

BOBBIO, Norberto. Dalla struttura alla funzione: nuovi studi di teoria del diritto. Roma: Laterza, 2007.

BLOCK, Marcella. Conflito de interesses nas sociedades anônimas: critério de apuração formal ou substancial? Revista de Direito Mercantil, Industrial, Econômico e Financeiro. São Paulo, n. 153/154, pp.36-65, 2010

et al. Dicionário de Política.v.1. 13. ed. Brasília: Editora Unb, 2007

BOERINGER, Charles-Henri et al. Les conflits d'intérêts dans l' enterprise: identifier, prevenir et gérer les conflits d'intéréts. Paris: LexisNexis, 2016.

BONAVIDES, Paulo. Do Estado Liberal ao Estado Social. 10. ed. São Paulo: Malheiros, 2011.

BONFIN, Natalia Bertolo. O Interesse Público nas Sociedades de Economia Mista. 2011. 124f. (Dissertação de Mestrado) - Faculdade de Direito da Universidade de São Paulo, São Paulo, 2011

BONOTTO, Laura. Articolo 2373 Conflito d'interessi. In: PICCIAU, Alberto (org.). Assemblea. In: MARCHETTI, Piergaetano et al (orgs.). Commentario alla riforma delle società. Milão: Giuffrè, 2008

BORGES, Aline Gonzalez. Supremacia do Interesse Público: Desconstrução ou Reconstrução? In: Revista de Direito do Estado. n.3, pp. 137-153, 2006.

BRANCO, Paulo Gustavo Gonet; COELHO, Inocêncio Mártires; MENDES, Gilmar Ferreira. Curso de Direito Constitucional. 5. ed. São Paulo: Saraiva, 2010. 
BREGLIA, Oreste. Conflitti d'interessi nelle deliberazioni delle società per azioni. Rivista del Diritto Commerciale e del Diritto Generale delle Obbligazioni. v. XX, pp. 654-678, 1922.

BUCCI, Maria Paula Dallari. Direito Administrativo e Políticas Públicas. São Paulo: Saraiva, 2006.

BUSI, Carlo Alberto. Assemblea e decisioni dei soci nelle società per azioni e nelle società a responsabilità limitata. In: GABRIELLI, Enrico; PICOZZA, Eugenio. (coords.) Trattato di Diritto dell'Economia. v.4. Pádua: CEDAM, 2008

CALABRESI, Guido; MELAMED, Douglas. Property Rules, Liability Rules and Inalienability: One view of the Cathedral. Harvard Law Review, n. 6, 1972.

CÂMARA, Jacintho Arruda. O lucro nas empresas estatais. Revista Brasileira de Direito Público - RBDP, n. 37, pp. 9-18, 2012.

CAMARGO, Sérgio Alexandre. Tipos de estatais. In: SOUTO, Marcos Juruena Villela (coord.). Direito administrative empresarial. Rio de Janeiro: Lumen Juris, 2006.

CANOTILHO, José Joaquim Gomes. Constituição Dirigente e Vinculação do Legislador: Contributo para a Compreensão das Normas Constitucionais Programáticas. Coimbra: Coimbra Editora, 1982

Direito Constitucional. 2. ed. Coimbra: Almedina, 1980.

CARNEIRO, Athos Gusmão. Sociedade de Economia Mista, prestadora de serviços públicos. Penhorabilidade de seus bens. Revista dos Tribunais. n. 749. São Paulo, pp. 141158,1998

CARRASQUEIRA, Simone de Almeida. Investimento das empresas estatais e endividamento público. Rio de Janeiro: Lumen Juris, 2006. 
Revisitando o regime jurídico das empresas estatais prestadoras de serviço público. In: (coord.) Direito administrativo empresarial. Rio de Janeiro: Lumen Juris, 2006, pp. 255-328.

CARNELUTTI, Francesco. Teoria generale del diritto. Camerino: Università di Camerino, Edizioni Scientifiche Italiane, 1998.

CARTIER-BRESSON, Anémone. L’état actionnaire. Paris: LGDJ, 2010

CARVAlHOSA, Modesto. A Ordem Econômica na Constituição de 1969. São Paulo: Revista dos Tribunais, 1972.

Comentário à Lei de Sociedades Anônimas. v.2. 5. ed. São

Paulo: Saraiva, 2011 .v. 4. t.1. 3.ed.

São Paulo: Saraiva, 2002

Considerações sobre o Direito Econômico. São Paulo:

Unidas, 1971.

Direito Econômico. São Paulo: Revista dos Tribunais, 1973.

. Sociedade de Economia Mista: Criação de Valor ou Política

Pública? In: SALLES, Marcos Paulo de Almeida; STAJN, Rachel; TEIXEIRA, Tarcisio (coords.). Direito Empresarial: Estudos em Homenagem ao Professor Haroldo Malheiros Duclerc Verçosa. São Paulo: IASP, 2015

CAVALCANTI, Themístocles Brandão. Sociedade de Economia Mista - Sua Natureza Seus Problemas. Revista de Direito Administrativo, n. 103, pp. 1-15, 1971.

CAVALLI, Gino (org.). Assemblea e amministratori. Turim: UTET Giuridica, 2013 
CESARINO JUNIOR, Antonio Ferreira. Direito Social Brasileiro. v.1. 6.ed. São Paulo: Saraiva, 1970

CLARK, Robert Charles. Corporate Law. Aspen: Law and Business, 1986.

COMPARATO, Fábio Konder, A Natureza da Sociedade Anônima e a Questão da Derrogabilidade das Regras Legais de Quórum nas Assembleias Gerais e Reuniões do Conselho de Administração. In: Novos Ensaios e Pareceres de Direito Empresarial. Rio de Janeiro: Forense, 1981.

Aspectos Jurídicos da Macro Empresa. São Paulo: Revista dos Tribunais, 1970

Controle Conjunto, Abuso no Exercício do Direito de Voto Acionário e Alienação Indireta de Controle Empresarial. In: Direito Empresarial: Estudos e Pareceres. São Paulo: Saraiva, 1990

Ensaio sobre a Constitucionalidade de Políticas Públicas.

Interesse Público, n. 16, pp. 49-63, 2002.

Estado, Empresa e Função Social. Revista do Tribunais, v.

732, pp. 38-46, 1996.

Função Social da Propriedade dos Bens de Produção. Revista de Direito Mercantil Industrial, Econômico e Financeiro, n. 63, pp. 71-79, 1986.

O Indispensável Direito Econômico. In: Ensaios e Pareceres de Direito Empresarial. Rio de Janeiro: Forense, 1978, pp. 453-472.

Ordem Econômica na Constituição Brasileira de 1988. In:

BARROSO, Luís Roberto; CLÈVE, Clemerson Merlin (orgs.). Doutrinas Essenciais:

Direito Constitucional. v. 6. São Paulo: Revista dos Tribunais, 2011, pp. 403-428. 
- Sociedade de Economia Mista Transformada em Sociedade Anônima Ordinária - Inconstitucionalidade. Revista Trimestral de Direito Público, n. 25, pp. 61-68, 1999.

; SAlOMÃo FILHO, Calixto. O Poder de Controle na

Sociedade Anônima. 6.ed. Rio de Janeiro: Forense, 2014

CHIARA, José Tadeu de. Moeda e Ordem Jurídica.1986. 166 f. Tese (Doutorado em Direito) - Faculdade de Direito da Universidade de São Paulo, São Paulo, 1986

CRAVEIRO, Mariana Conti. Aspectos societários da participação do Estado em sociedades anônimas. 2007. 178f. Dissertação (Mestrado em Direito) - Faculdade de Direito da Universidade de São Paulo, São Paulo, 2007

CRETELLA JUNIOR, José. Conceito Moderno de Serviço Público. Revista da Faculdade de Direito da Universidade de São Paulo. n. 61. n. 2, São Paulo, 1966, pp. 190-236

Anulação do ato administrativo por desvio de poder. Rio de Janeiro: Forense, 1978

DALCASTEL, Marcia Bataglin. Conflito de interesses na sociedade de economia mista.: “interesse público" versus “interesse privado". 2011. 171f. Tese (Doutorado em Direito Público) - Faculdade de Direito, Universidade do Estado do Rio de Janeiro, Rio de Janeiro, 2011

DALTON, Hugh. Princípios de Finanças Públicas. 4. ed. São Paulo: FGV, 1980.

DALLARI, Dalmo de Abreu. Elementos de teoria geral do Estado. 30.ed. São Paulo: Saraiva, 2011

DAVIS, Carvalho de Britto. Tratado das Sociedades de Economia Mista. V. 1. Rio de Janeiro: José Konfino, 1969.

DI PIETRO, Maria Sylvia Zanella. Direito Administrativo. 27.ed. São Paulo: Atlas, 2014 
; ALVES, Carlos Vinícius (coords.). Supremacia do interesse público e outros temas relevantes do direito administrativo. São Paulo: Atlas, 2010

DUGUIT, Léon. El Servicio Público in Las Transformaciones Del Derecho (Público y Privado). Buenos Aires: Editorial Helialista, 1975.

DULliUS, Adriana Cristina. Sociedades de Economia Mista e Aspectos do Exercício do Poder de Controle. Revista de Direito Bancário e do Mercado de Capitais. v. 82. São Paulo, pp. 15-51, 2018

EIZIRIK, Nelson. A Lei das S.A. Comentada. v. I e III. São Paulo: Quartier Latin, 2011.

O Estado como Acionista Controlador de Companhias Integrantes do Mercado Acionário - O Caso "Vale”. In: EIZIRIK, Nelson. Questões de Direito Societário e de Mercado de Capitais. Rio de Janeiro: Forense, 1987, pp. 34-58.

ESTORNINHO, Maria João. A fuga para o Direito Privado: Contributo para o Estudo da Atividade de Direito Privado da Administração Pública. Coimbra: Almedina, 1996.

FERREIRA, Waldemar Martins. A Sociedade de Economia Mista. São Paulo: Max Limonad, 1956.

FRANÇA, Erasmo Valladão Azevedo Novaes e. Ainda o conceito de benefício particular: anotações ao julgamento do processo CVM N. RJ-2009/5.811. In: Conflito de interesses nas assembleias nas assembleias de S.A., (e outros escritos sobre conflito de interesses). 2. ed. São Paulo, Malheiros, 2014.

Conflito de interesses nas assembleias de

S.A., e outros escritos sobre conflito de interesses. 2. ed. São Paulo: Malheiros, 2014 
Conflito de Interesses: formal ou substancial? Nova decisão da CVM sobre a questão. Revista de Direito Mercantil, Industrial, Econômico e Financeiro. São Paulo, n. 128, pp. 225-262, 2002 - Conflito de interesses e benefício particular: distinção. In: Conflito de interesses nas assembleias nas assembleias de S.A., (e outros escritos sobre conflito de interesses). 2. ed. São Paulo: Malheiros, 2014 - Lineamentos da Reforma do Direito Societário Italiano em Matéria de Invalidade das Deliberações Assembleares. Revista de Direito Mercantil, Industrial, Econômico e Financeiro, n. 154, São Paulo: Malheiros, pp. $12-24,2004$

ADAMEK, Marcelo Vieira Von. Affectio societatis: um conceito jurídico superado no moderno direito societário pelo conceito de fim social. Revista de Direito Mercantil, Industrial, Econômico e Financeiro, n. 149, 2008.

FIGUEIREDO, Lucia Valle. Empresas públicas e sociedades de economia mista. São Paulo: RT, 1978.

FIORI, José Luís. Os moedeiros falsos. Folha de S. Paulo, São Paulo, 3 de julho de 1994

FREIRE, André Luiz. O regime de direito público na prestação de serviços públicos por pessoas privadas. 2013. 429f. Tese (Doutorado em Direito) - Faculdade de Direito da Pontifícia Universidade Católica

FURTADO, Celso. Desenvolvimento e Subdesenvolvimento. Rio de Janeiro: Contraponto, 2009.

Teoria e Política do Desenvolvimento Econômico. São Paulo: Companhia Editora Nacional, 1967.

Subdesenvolvimento e Estado Democrático. Recife: Condepe, 1962. 
GALGANO, Francesco. Trattato di Diritto Comerciale e di Diritto Publico dell'economia.v.1. Pádua: CEDAM, 2003.

, Storia del Diritto Commerciale. Bolonha: Mulino, 1976.

GAMBINO, Agostino. Il Principio di Correttezza nell'ordinamento delle Società per Azioni (Abuso di Potere nel Procedimento Assembleare). Milão: Giuffrè, 1987.

, La disciplina Del conflito di interessi del socio. Rivista del Diritto Commerciale, v. I, pp. 371-425, 1969.

, Nuove Prospettive del Conflitto di Interessi Assembleare nella

Società per Azioni. Rivista del Diritto Commerciale e del Diritto Generale delle Obligazzioni. n.2. Ano CIX, pp. 379-396, 2011

GOMES, Orlando; VARELA, Antunes. Direito Econômico. São Paulo: Saraiva, 1977.

GRAU, Eros Roberto. A ordem econômica na Constituição de 1988. 11. ed. São Paulo: Malheiros, 2006.

. Constituição e Serviço Público. In: GRAU, Eros Roberto; GUERRA FILHO, Willis Santiago (orgs.). Direito Constitucional - Estudos em Homenagem a Paulo Bonavides. São Paulo: Malheiros, 2001.

. Elementos de Direito Econômico. São Paulo: Revista dos

Tribunais, 1981.

. Licitação e Contrato Administrativo. São Paulo: Malheiros, 1995.

Lucratividade e Função Social nas Empresas sob Controle do Estado. Revista de Direito Mercantil, Industrial, Econômico e Financeiro. n.55. São Paulo, pp. 35-59, 1984 
O direito posto e o direito pressuposto. 7. ed. São Paulo:

Malheiros, 2008.

Planejamento Econômico e Regra Jurídica. São Paulo: Revista dos Tribunais, 1978.

Sociedade de economia mista - Nulidade de acordo de acionistas que importa em mudança do seu controlador. Revista de Direito Administrativo, n. 222, 2000.

Sociedades de Economia Mista, Empresas Públicas, Fundações e Autarquias prestadoras de serviços públicos: o tema do lucro. Revista Trimestral de Direito Público. São Paulo. n. 6, pp. 269-276, 1994

GUERREIRO, José Alexandre Tavares. Conflito de Interesses entre Sociedade Controladora e Controlada e entre Coligadas, no Exercício do Voto em Assembleias Gerais e Reuniões Sociais. In: Revista de Direito Mercantil, Industrial, Econômico e Financeiro, n.51, pp. 29-32, 1983

, Direito das Minorias na Sociedade Anônima. Revista de Direito Mercantil, Industrial, Econômico e Financeiro, n. 63, 1986.

O Estado e a Economia dos Contratos Privados.

Revista de Direito Mercantil, Industrial, Econômico e Financeiro. n. 31. São Paulo, pp. 77-88, 1978

Sobre a Interpretação do Objeto Social. Revista de

Direito Mercantil, Industrial, Econômico e Financeiro, n.54, pp. 67-72, 1984.

Sociologia do poder da sociedade anônima. Revista

de Direito Mercantil, Industrial, Econômico e Financeiro, n. 77, 1990.

; TEIXEIRA, Egberto Lacerdo. Das Sociedades

Anônimas no Direito Brasileiro. v. II. São Paulo: Bushatsky, 1979 
GUIZZI, Giuseppe. L'interesse sociale nelle società pubbliche. In: AULETTA, Ferruccio (org.). I Controlli nelle società pubbliche. Bolonha: Zanichelli Editore, 2017, pp. 3-99

HACHEM, Daniel Wunder. O suposto caráter autoritário da supremacia do interesse público e das origens do Direito Administrativo: uma crítica da crítica. In: DI PIETRO, Maria Sylvia; RIBEIRO, Carlos Vinícius Alves (coords.). Supremacia do interesse público e outros temas relevantes. São Paulo: Atlas, 2010

HIRSCHMAN, Albert. The Strategy of Economic Development. New Haven: Yale University Press, 1958.

IANNI, Octavio. Estado e Planejamento Econômico no Brasil. Rio de Janeiro: Editora Civilização Brasileira, 1971.

IRTI, Natalino. L'ordine Giuridico del Mercato. Roma: Laterza, 2001.

JACQUEMIN, Alex; SCHRANS, Guy. Le Droit Économique. 2. ed. Paris: Presses Universitaires de France, 1974.

JAEGER, Pier Giusto. L’interesse sociale. Milão: Giufrè, 1964.

L'interesse sociale rivisitato (Quarant'anni dopo). Giurisprudenzia

Commerciale, v.1, 2000

JENSEN, Michael; MECKLING, William. Theory of the firm: managerial behavior, agency costs and ownership structure. Journal of financial economics, n. 3, 1976

JHERING, Rudolph von. A evolução do Direito (trad.). Lisboa: José Bastos, 1892.

A luta pelo direito trad. João Vasconcelos. Rio de Janeiro:

Forense, 2007 
JUSTEN FILHO, Marçal. Empresa, ordem econômica e Constituição. Revista de Direito Administrativo - RDA, n. 212, pp. 109-133, 1998.

Conceito de interesse público e a "personalização" do direito administrativo. Revista Trimestral de Direito Público. São Paulo, n. 26, pp. 115-136, 1999

. Empresas Estatais e a Superação da Dicotomia "Prestação de Serviço público/exploração de atividade econômica". In: FIGUEIREDO, Marcelo; PONTES FILHO, Valmir (orgs.). Estudos de Direito Público em homenagem a Celso Antônio Bandeira de Mello. São Paulo; Malheiros, 2008

O Regime Jurídico das Empresas Estatais e a Distinção entre "Serviço Público" e "Atividade Econômica”. Revista de Direito do Estado. n.1, pp. 119135,2006

Os Serviços Públicos e as Diversas Formas de Prestação. In:

Cardozo, José Eduardo Martins et al. (coords.), Direito Administrativo Econômico. São Paulo: Atlas, 2011, pp. 369-575

Serviço público no Direito brasileiro. In: Cardozo, José Eduardo

Martins - Queiroz, João Eduardo Lopes - Santos, Márcia Walquiria Batista dos Santos (coords.), Direito Administrativo Econômico, São Paulo, Atlas, 2011

KEYNES, John Maynard. Teoria Geral do Emprego, do Juro e da Moeda. São Paulo: Atlas, 1982.

L’État Actionnaire. Paris: Rapport public thématique, 2017.

LAMY FILHO, Alfredo; PEDREIRA, José Luis Bulhões. A Lei das S.A.: Pressupostos, Elaboração, Aplicação. v. II. Rio de Janeiro: Forense, 1996.

LAUBADÈRE, André de. Droit Public Économique. 2. ed. Paris: Dalloz, 1976 
LEÃES, Luiz Gastão Paes de Barros. Conflito de Interesses. In: Estudos e Pareceres sobre Sociedades Anônimas. São Paulo: Revista dos Tribunais, 1986, pp. 24-25

O Conceito Jurídico de Sociedade de Economia Mista. In: DI PIETRO, Maria Sylvia Zanella; SUNDFELD, Carlos Ari (orgs.). Doutrinas Essenciais: Direito Administrativo. v. 6. São Paulo: Revista dos Tribunais, 2012, pp. 735758.

Conflito de Interesses e Vedação de Voto nas Assembleias das Sociedades Anônimas. Revista de Direito Mercantil, Industrial, Econômico e Financeiro, n. 92, 1993

Proibição de Voto e Conflito de Interesse nas Assembleias Gerais - Ação de Anulação de Deliberação Assemblear decorrente de Voto de Acionista com Interesse Conflitante. In: Pareceres. v. 1. São Paulo: Singular, 2004.

LUCAS, Fábio. Conteúdo Social nas Constituições Brasileiras. Belo Horizonte: UFMG, 1959.

LUCENA, José Waldecy. Das sociedades anônimas - comentários à lei. v.3. Rio de Janeiro: Renovar, 2012

LUNA, Everardo da Cunha. Abuso de Direito. Rio de Janeiro: Forense, 1959.

MARCHETTI, Piergaetano et al. Commentario all riforma dele società. Milão: Giuffrè, 2008

MARINHO, Josaphat. A ordem Econômica nas Constituições Brasileiras. In: BARROSO, Luís Roberto; CLÈVE, Clemerson Merlin (orgs.). Doutrinas Essenciais: Direito Constitucional. v. 6. São Paulo: Revista dos Tribunais, 2011, pp. 629-641

MARQUES NETO, Floriano de Azevedo. A Nova Regulamentação dos Serviços Públicos.

Revista Eletrônica de Direito Administrativo Econômico. Salvador. n. 1, 2005. Disponível em http://www.direitodoestado.com.br. Acesso em: 04 de abril de 2019 
MARTINS, Fran. Comentários à Lei das Sociedades Anônimas. v. II, t. I, Rio de Janeiro: Forense, 1978 v. III

MAXILIANO, Carlos. Hermenêutica e Aplicação do Direito. 3. ed., Freitas Bastos, 1941.

MEDAUAR, Odete. Nova Crise do Serviço Público. In: CUNHA, Sérgio Sérvula da; GRAU, Eros Roberto (orgs.). Estudos de Direito Constitucional em Homenagem a José Afonso da Silva. São Paulo: Malheiros, 2002, pp. 527-538

MEIRELLES, Hely Lopes. Direito Administrativo Brasileiro. 9. ed. São Paulo: Revista dos Tribunais, 1982.

MELlO, Celso Antonio Bandeira. Curso de Direito Administrativo. 26. ed. São Paulo: Malheiros, 2008.

\section{Prestação de Serviços Públicos e Administração}

Indireta. São Paulo: Revista dos Tribunais, 1975

. Natureza essencial das sociedades de economia mista e empresas públicas: consequências em seus regimes. In: Grandes temas de direito administrativo. São Paulo: Malheiros, 2010, pp. 329-338.

. Serviço Público e sua Feição Constitucional no Brasil.

Direito do Estado Novos Rumos, v. 02, São Paulo, p. 13-35, 2001

Sociedades de economia mista, empresas públicas e o regime de direito público. In: Grandes temas de direito administrativo.

São Paulo: Malheiros, 2010, pp. 339-349

MENDONÇA, José Xavier Carvalho de. Tratado de Direito Comercial Brasileiro. Rio de Janeiro: Freitas Bastos, 1961. 
MENGONI, Luigi. Appunti per uma revisione della teoria sul conflitto di interessi nelle deliberazioni di assemblea della società per azioni. Rivista delle Società. n. 1, 1956.

MESSINEO, Francesco. Il Contratto in Genere. t.1. Milão: Giuffrè, 1973.

MIRANDA, Francisco Cavalcante Pontes de. Tratado de Direito Privado. Rio de Janeiro: Borsoi, 1954.

MIRANDA JÚNIOR, Darci Arruda. Breves comentários à lei de sociedades por ações. São Paulo: Saraiva, 1977

MOREIRA, Vital. A Ordem Jurídica do Capitalismo. Coimbra: Centelha, 1973. Economia e Constituição. Coimbra: Coimbra Editora, 1979.

OCTAVIANI, Alessandro; NOHARA, Irene Patrícia. Estatais. São Paulo: Thomson Reuters Brasil, 2019

OLIVERCRONA, Karl. Derecho como Hecho. Buenos Aires: De Palma, 1959.

OSÓRIO, Fábio Medina. Existe uma Supremacia do interesse público sobre o privado no direito administrativo brasileiro? Revista de Direito Administrativo, Rio de Janeiro, n. 220, pp- 69-107, abr/jun 2000

PAIVA, Alfredo de Almeida. As sociedades de economia mista e as empresas públicas como instrumentos jurídicos a serviço do Estado. Revista de Direito Administrativo - RDA, seleção histórica (1945-1995), Rio de Janeiro, pp. 29-38.

PARENTE, Norma Jonssen, O Acionista em Conflito de interesses. In: KALANSKY, Daniel; PERIN JUNIOR, Eric; PEYSER, Luis (coords.). Direito Empresarial: Aspectos Atuais de Direito Empresarial Brasileiro e Comparado. São Paulo: Método, 2005. 
PARGENDLER, Mariana. Evolução do Direito Societário - Lições do Brasil. São Paulo: Direito GV, 2013.

PELA, Juliana Krueger. As Golden shares no direito brasileiro. São Paulo: Quartier Latin, 2012.

PENTEADO, Mauro Rodrigues. As Empresas Estatais e os Sistemas de Supervisão e Controle. Revista de Direito Mercantil Industrial, Econômico e Financeiro, n. 45, 1982. . Caracterização Jurídica das Sociedades de Economia Mista Revista de Direito Mercantil Industrial, Econômico e Financeiro, n. 43, 1981.

As Sociedades de Economia Mista e as Empresas Estatais perante a Constituição de 1988. Revista de Direito Mercantil, Industrial, Econômico e Financeiro, São Paulo, v. 73, 1989, pp. 5-21

PEREIRA, Tadeu Rabelo. Regime(s) jurídico(s) das empresas estatais que exploram atividade econômica. 2000. 181f. Dissertação (Mestrado em Direito) - Faculdade de Direito da Universidade de São Paulo, São Paulo, 2000

PETTER, Lafayete. Princípio Constitucionais da Ordem Econômica - O Significado e o Alcance da Constituição Federal. 2. ed. São Paulo: RT, 2008.

PINTO, Bilac. O Declínio das Sociedades de Economia Mista e o Advento das Modernas Empresas Públicas. In: Estudos sobre a Constituição Brasileira. Rio de Janeiro: Fundação Getúlio Vargas, 1954

PINTO JUNIOR, Mario Engler. Empresa Estatal - Função Econômica e Dilemas Societários. São Paulo: Atlas, 2010.

PIZZORUSSO, Alessandro. Interesse pubblico e interessi pubblici. Rivista Trimestrale di Diritto e Procedura Civile. n. 1. 1972, pp. 57-87, Milano: Giuffrè 
PRESBICH, Raúl. El Desarrollo Economico de la America Latina y Algunos de sus Principales Problemas. CEPAL, 1948.

RAÓ, Vicente. Ato Jurídico. 2. ed. São Paulo: Saraiva, 1979.

O Direito e a Vida dos Direitos. v.1, São Paulo, Max Limonad, 1960.

RANGEON, François. L’ideologie de l’ interêt général. Paris: Economica, 1986

RATHENAU, Walther. La realtà della società per azioni - Rifflessioni suggerite dall'esperienza degli affair. Rivista della Societá. n 4-5, pp. 912-947 , 1960

REGO, Marcelo Lamy. Conflito de Interesses. In: LAMY FILHO, Alfredo; e PEDREIRA, José Luiz Bulhões (coords.). Direito das Companhias. v. I. Rio de Janeiro: Forense, 2009

REQUIÃO, Rubens. A Sociedade Anônima como "Instituição". Revista de Direito Mercantil, Industrial, Econômico e Financeiro. São Paulo, n. 18, pp. 25-29, 1975

RIBEIRO, Marcia Carla Pereira. Sociedade de economia mista e empresa privada: estrutura e função. Curitiba: Juruá, 2001.

RIBEIRO, Renato Ventura. Direito de Voto nas Sociedades Anônimas. São Paulo: Quartier Latin, 2009.

RICCIO, Angelo. Il presidente dell'assemblea può, dunque, escludere dal quorum deliberativo il voto espresso dal socio in conflitto di interessi. Contratto e impresa n. 3 , pp. 1079-1082, 2001.

ROSSI, Adriano, Profili Giuridici della Società a Partecipazione Statale. Milão: Giufrè, 1977.

ROUBIER, Paul. Droit Subjetifs et Situations Juridiques. Paris: Dalloz, 2005 Théorie Générale du droit. Paris: Dalloz, 2005. 
SALOMÃO FILHO, Calix to. O Novo Direito Societário. 4. ed, São Paulo: Malheiros, 2011. . Sociedade Anônima: Interesse Público e Privado. Revista de Direito Mercantil Industrial, Econômico e Financeiro, n. 127, pp. 7-20, 2002.

SANDULLI, Michele; SANTORO, Vittorio. La riforma delle Società. t.1. Turim: G. Giappichelli Editore, 2010.

SARMENTO, Daniel (coord.). Interesses Públicos versus Interesses Privados: desconstruindo o princípio da supremacia do interesse público. Rio de Janeiro: Lumen Juris, 2007

SCHILLING, Arno. Sociedades de economia mista. Revista de Direito Administrativo, n. 50, pp. 36-46, 1957.

SCHIRATO, Vitor Rhein. Novas Anotações sobre as Empresas Estatais. Revista de Direito Administrativo. v. 239. Rio de Janeiro, pp. 209-240, 2005

SCHMIDT, Dominique. Les conflits d'intérêts dans la Société anonyme. Paris: Joly, 2004.

SCHUMPETER, Joseph Alois. A Teoria do Desenvolvimento Econômico (trad.). 2. ed. São Paulo: Nova Cultural, 1985.

SCHWIND, Rafael Wallbach. O Estado Acionista: empresas estatais e empresas privadas com participação estatal. São Paulo: Almedina, 2017.

\section{Participação Estatal em Empresas Privadas: As}

“Empresas Público Privadas". 2014. 370f. Tese (Doutorado em Direito) - Faculdade de Direito da Universidade de São Paulo, São Paulo, 2014

SILVA, Almiro do Couto e. Privatização no Brasil e o Novo Exercício das Funções Públicas por Particulares. Revista Eletrônica sobre Reforma do Estado, n.16, 2009, disponível em 
[http://www.direitodoestado.com/revista/RERE-16-DEZEMBRO-2008

ALMIRO\%20COUTO.pdf], acesso em 03 de junho de 2016.

SILVA, Ives Gandra da; VIDIGAL, Geraldo de Camargo. Comentários à Lei das Sociedades por Ações. São Paulo: Editora Resenha Universitária, 1978.

SILVA José Afonso da. Comentário Contextual à Constituição. 9. ed. São Paulo: Malheiros, 2014.

Curso de Direito Constitucional Positivo. 30. ed. São Paulo:

Malheiros, 2008.

SIMIONATO, Frederico Augusto Monte. Sociedades anônimas \& Interesse social. Curitiba: Juruá Editora,2014

SOUZA, Eduardo Nunes de. Situações Jurídicas Subjetivas: Aspectos Controversos. Civilistica.com. Rio de Janeiro: a. 4, n. 1, 2015. Disponível em http://civilistica.com/wpcontent/uploads/2015/08/Souza-civilistica.com-a.4.n.1.2015.pdf acesso em 06.06.2018

SOUZA, Washington Peluso Albino de. Direito Econômico. São Paulo: Saraiva, 1980.

Do Direito Econômico nas Constituições Vigentes.

Revista Brasileira de Estudos Políticos, 1970

Primeiras Linhas de Direito Econômico. 3. ed., São Paulo: Revista dos Tribunais, 1994.

. Teoria da Constituição Econômica. Belo

Horizonte: Del Rey, 2002.

SUNDFELD, Carlos Ari. A submissão das empresas estatais ao direito privado: uma definição histórica do STF. Boletim de direito administrativo - BDA, Ano XI, n. 5, pp. 286-290, 1995. 
A Participação Privada nas Empresas Estatais. In: SUNDFELD,

Carlos Ari (coord.). Direito Administrativo Econômico. São Paulo: Malheiros, 2000. Entidades Administrativas e Noção de Lucro. Revista Trimestral de Direito Público, n. 6, 1994.

TELLES JUNIOR, Goffredo. Filosofia do Direito. t.2, São Paulo: Max Limonad, 1967.

O Direito Quântico: Ensaio sobre o Fundamento da Ordem

Jurídica. 3. ed. São Paulo: Max Limonad, 1980.

TONIN, Mayara Gasparotto. Sociedades de Economia Mista e Acionistas Minoritários. São Paulo: Quartier Latin, 2018

TRIMARCHI, Pietro. Rischio e Responsabilità Oggetiva. Milano: Giuffrè, 1961.

VALENTINI, Stelio. L'impresa pubblica: lineamenti giuridici. Milão: Giufrè, 1980.

VALVERDE, Trajano de Miranda. Sociedades por Ações (comentários ao decreto-lei $\mathbf{n}^{\mathbf{0}}$ 2.627, de 26 de setembro de 1940). 3. ed. Rio de Janeiro: Forense, 1959.

Sociedades anônimas ou companhias de economia mista. Revista de Direito Administrativo - RDA, seleção histórica 1945-1995, pp. 29-38.

VENÂNCIO FILHO, Alberto. A Intervenção do Estado no Domínio Econômico: O Direito Público Econômico no Brasil. Rio de Janeiro: Fundação Getúlio Vargas, 1968.

Sociedades de Economia Mista In: LAMY FILHO, Alfredo; PEDREIRA, José Luiz Bulhões (coords.). Direito das Companhias. v. II. Rio de Janeiro: Forense, 2009

VERÇOSA, Haroldo Malheiros, Duclerc. Curso de Direito Comercial. v.3. 2.ed. São Paulo: Malheiros, 2012 
VIDIGAL, Geraldo de Camargo. Fundamentos de Direito Financeiro. São Paulo: Revista dos Tribunais, 1972.

Teoria Geral do Direito Econômico. São Paulo: Revista dos Tribunais, 1977.

WALD, Alexandre Mendonça. Acordo de Acionistas e Interesses Sociais. In: FONSECA, Rodrigo Garcia da; WALD, Arnoldo. A Empresa no Terceiro Milênio: Aspectos Jurídicos. São Paulo: Juarez de Oliveira, 2005

WALD, Arnoldo. As sociedades de economia mista e as empresas públicas no direito comparado. Revista Forense, v. 152, pp. 510-523, 1954.

As Sociedades de Economia Mista e a Nova Lei das Sociedades Anônimas. Revista de Informação Legislativa, n.54, 1977.

WEBER, Max. Economia y Sociedad. Trad. Eugenio Imaz et. al. Cidade do México: Fondo de Cultura Economica, 1944 


\section{JURISPRUDÊNCIA E JULGADOS ADMINISTRATIVOS CITADOS}

BRASIL. Comissão de Valores Mobiliários. Inquérito Administrativo CVM no TA/RJ2001/4977. Relatora: Norma Parente. Rio de Janeiro, 19 de dezembro de 2001. O relatório e os votos dos diretores encontram-se disponíveis em [http://www.cvm.gov.br/sancionadores/sancionador/2001/20011219_RJ20014977.html]. Acesso em 26.08.2019

\section{Inquérito Administrativo CVM no}

TA-RJ2002/1153. Relatora: Norma Parente. Rio de Janeiro, 06 de novembro de 2002. O relatório e os votos dos diretores encontram-se disponíveis em [http://www.cvm.gov.br/sancionadores/sancionador/2002/20021106_RJ20021153.html]. Acesso em 26.08.2019

\section{Processo Administrativo CVM no RJ}

2009/13179, relator Alexsandro Broedel Lopes, julgado em 09 de setembro de 2010. O relatório e os votos dos diretores encontram-se disponíveis em [http://www.cvm.gov.br/decisoes/2010/20100909_R1/20100909_D09.html]. Acesso em 26.08.2019

\section{Processo Administrativo CVM $\mathbf{n}^{\circ}$}

RJ/2013/6635. Relatora: Luciana Dias. Rio de Janeiro, 26 de maio de 2015. O relatório e os votos dos diretores encontram-se disponíveis em [http://www.cvm.gov.br/export/sites/cvm/sancionadores/sancionador/anexos/2015/201505 26_PAS_RJ20136635.pdf]. Acesso em 01.09.2019

\section{Processo Administrativo CVM $\mathbf{n}^{\circ}$}

19957.005749/2017-29. Relator: Leonardo Pereira. Rio de Janeiro. Caso julgado nas sessões de 14.07.2017, 05.09.2019, 12.09.2017 e 26.09.2017. O relatório e os votos dos diretores encontram-se disponíveis em:

[http://www.cvm.gov.br/decisoes/2017/20170714_R1/20170717_D0728.html]; [http://www.cvm.gov.br/decisoes/2017/20170905_R1/20170905_D0728.html]; [http://www.cvm.gov.br/decisoes/2017/20170912_R1/20170912_D0728.html]; 
[http://www.cvm.gov.br/decisoes/2017/20170926_R1/20170926_D0728.html]. Acesso em 04.09.2019

\section{Processo CVM no 19957.007563/2017-}

12. Rio de Janeiro, 29 de agosto de 2017. O relatório e os votos dos diretores encontram-se disponíveis em [http://www.cvm.gov.br/decisoes/2017/20170829_R2.html]. Acesso em 01.09 .2019

. Processo Administrativo Sancionador

CVM n' RJ2015/10677. Relator: Henrique Balduíno Machado Moreira. Rio de Janeiro, 7 de fevereiro de 2017.2 Disponível em [http://www.cvm.gov.br/export/sites/cvm/sancionadores/sancionador/anexos/2017/RJ2015 10677_PETROBRAS_2.pdf], acesso em 23.10.2019

BRASIL. Superior Tribunal de Justiça. Recurso Especial no 131.300 - RS. Relator: Cesar Asfor Rocha. Quarta Turma. Brasília, 29 de agosto de 2000

BRASIL. Conselho de Recursos do Sistema Financeiro Nacional. Processo $\mathbf{n}^{\mathbf{0}}$ 10372.000246/2016-82. Relator: Flávio Maia Fernandes dos Santos. Brasília, 28 de junho de 2017

BRASIL. Supremo Tribunal Federal. Ação Cautelar 669-4/SP. Relator: Carlos Brito. Tribunal Pleno. Julgamento em 25.05.2011.

. Recurso Extraordinário 220906-DF, Tribunal

Pleno, Brasília, DF, 16 de novembro de 2000

BRASIL. Tribunal de Justiça de São Paulo. Agravo de Instrumento no 416.635.4/0-00. Relator: Sérgio Gomes. 9ª Câmara de Direito Privado. São Paulo, 7 de fevereiro de 2006 